\title{
Proposition of a Mechanism for the Electrochemical Oxidative Coupling of Methane
}

\author{
Cristiane A. da Silva ${ }^{1}$, Paulo Emílio V. de Miranda ${ }^{2}$
}

\author{
${ }^{1}$ LBCD-LADETEC, Chemistry Institute, Federal University of Rio de Janeiro \\ ${ }^{2}$ The Hydrogen Laboratory, PEMM-Coppe-Federal University of Rio de Janeiro
}

The production of ethylene and its oxide, raw material for a host variety of products nowadays used in our society, is done with the use of naphtha, a derivative of oil. However, the present availability of natural gas and, of biogas more recently, has open prospects for the production of ethylene from methane, using a chemical route, by the chemical oxidative coupling of methane, which reacts with oxygen yielding ethylene and water [1]. Gaseous oxygen must be reduced to the species O2- by a catalyst, which must be highly basic (donator of electrons). Nevertheless, other oxygen species $\left(\mathrm{O}-, \mathrm{O}_{2}{ }^{2-}\right)$ may be formed at the catalyst surface and are deleterious to the selectivity to $\mathrm{C}_{2}$ hydrocarbons. Although not yet industrially established, this process presents important environmental advantages, for utilizing methane from fossil origin less pollutant than oil and even opens the possibility to decrease the environmental impact of the present chemical industry as a whole.

Recently, a new alternative was proposed, with several environmental, economic and social advantages compared to the present industrial standard that is based in the use of naphtha and yet even compared to the methane chemical oxidative coupling $[1,2]$. It is a process that launches a new procedure of methane electrochemical oxidative coupling. In this case a solid oxide fuel cell, SOFC, is used as an electrochemical reactor in which other electrochemical reactions are privileged to take place instead of the conventional oxidation of the fuel at the fuel cell anode to produce $\mathrm{CO}_{2}$, water vapor and electrons. This is the CSOFC, a reactor capable of making the electrochemical conversion of methane into chemicals. One of the main advantages of this option is the fact that there is continuous generation of $\mathrm{O}^{2-}$, which are delivered by the electrolyte to the fuel cell anode triple phase regions, where the electrochemical reactions of interest take place. That is where methane react electrochemically with the oxygen ions to generate $\mathrm{C}_{2}$ type hydrocarbons by the following reactions:

$$
\begin{aligned}
& 2 \mathrm{CH}_{4}+2 \mathrm{O}^{2-} \rightarrow \mathrm{C}_{2} \mathrm{H}_{4}+2 \mathrm{H}_{2} \mathrm{O}+4 \mathrm{e}^{-} \\
& 2 \mathrm{CH}_{4}+\mathrm{O}^{2-} \rightarrow \mathrm{C}_{2} \mathrm{H}_{6}+\mathrm{H}_{2} \mathrm{O}+2 \mathrm{e}^{-}
\end{aligned}
$$

A probable mechanism for the methane electrochemical oxidative coupling reaction is schematically represented in Figure 1. The electrolyte acts as a dense and selective membrane that delivers $\mathrm{O}^{2-}$ ions to the reaction environment. These are highly basic species responsible for splitting the methane $\mathrm{C}-\mathrm{H}$ bond, which privilege $\mathrm{C}_{2}$ hydrocarbon formation instead of the formation of carbon oxides $\left(\mathrm{CO}\right.$ and $\left.\mathrm{CO}_{2}\right)$. As represented schematically in Figure 1, the $\mathrm{O}^{2-}$ ions present in the electrocatalyst crystalline lattice present high bonding energy and react with the hydrogen atom to form the methyl radical $\left(\mathrm{CH}_{3}\right)$. These radicals are very reactive species that dimerize to form ethane $\left(\mathrm{C}_{2} \mathrm{H}_{6}\right)$ to subsequently undergo dehydrogenation and form ethylene $\left(\mathrm{C}_{2} \mathrm{H}_{4}\right)$. 
The cations play a fundamental role on the system selectivity. The acidity level generated by the positive charges must be sufficiently low or moderate in order to minimize intermediary reactions, that is, highly acid sites are deleterious to selectivity because they interact strongly with the methyl radical, thus favoring the complete oxidation reaction.

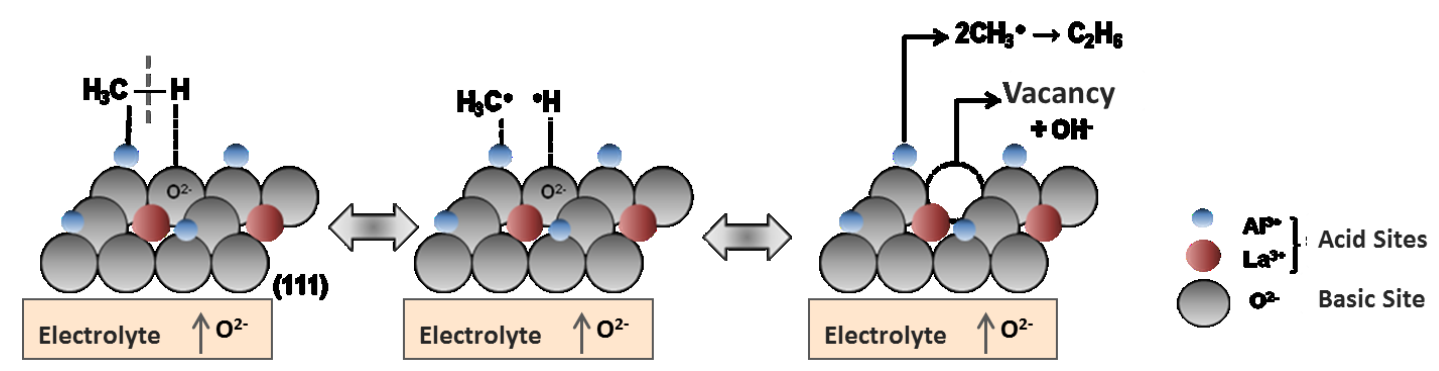

Figure 1: Schematic representation proposed for the methane electrochemical oxidative coupling reation in a SOFC-type reactor.

Furthermore, it may be perceived that the utilization of a SOFC-type reactor eliminates the need for a catalytic element to produce the $\mathrm{O}^{2-}$ ion that is essential for the formation of ethylene and ethane. The reason for that is because this species is already available in the fuel cell by means of the reaction that takes place in the cathode and selectively transfers these ions to the anode throughout the electrolyte. Moreover, the CSOFC reactor herein treated and supported by previous work [1,2] makes viable the application of this technology for the co-generation of chemicals $\left(\mathrm{C}_{2}\right.$-type hydrocarbons), heat and electric energy from the direct utilization of methane. The electrocatlysts synthesizing methods necessary for the present case have been developed [3].

\section{Acknowledgment}

The authors would like to acknowledge the financial support to this research from Funtec-BNDES, Oxiteno S.A. and EnergiaH Ltda, grant n_ 11.2.0323.

\section{BIBLIOGRAPHY}

[1] MIRANDA, P. E. V. "Materials for a new paradigm of the chemical industry", Matéria, v. 20, n. 3, pp. IIII, 2015.

[2] MIRANDA, P. E. V., VENÂNCIO, S. A., GUTIERRES, T. E. F., et al., "Method for the production of light hydrocarbons form gas with high methane content, a solid oxide fuel cell used for the production of light hydrocarbons from gas with high methane content, and a catalyst for the production of light hydrocarbons from gas with high methane content”, US Patent 9,281,525 B2, 2016.

[3] SILVA, C. A., MIRANDA, P. E. V. Synthesis of LaAlO3 based materials for potential use as methane fueled solid oxide fuel cell anode, International Journal of Hydrogen Energy, v. 40, pp. 10002-10015, 2015. 